University of Nebraska - Lincoln

DigitalCommons@University of Nebraska - Lincoln

Papers in the Earth and Atmospheric Sciences

Earth and Atmospheric Sciences, Department

$1-2008$

\title{
Reef Foraminifera as Bioindicators of Coral Reef Health: Low Isles Reef, Northern Great Barrier Reef, Australia
}

Jonathan D. Schueth

University of Nebraska-Lincoln

Tracy D. Frank

University of Nebraska-Lincoln, tfrank2@unl.edu

Follow this and additional works at: https://digitalcommons.unl.edu/geosciencefacpub

Part of the Earth Sciences Commons

Schueth, Jonathan D. and Frank, Tracy D., "Reef Foraminifera as Bioindicators of Coral Reef Health: Low Isles Reef, Northern Great Barrier Reef, Australia" (2008). Papers in the Earth and Atmospheric Sciences. 101.

https://digitalcommons.unl.edu/geosciencefacpub/101

This Article is brought to you for free and open access by the Earth and Atmospheric Sciences, Department of at DigitalCommons@University of Nebraska - Lincoln. It has been accepted for inclusion in Papers in the Earth and Atmospheric Sciences by an authorized administrator of DigitalCommons@University of Nebraska - Lincoln. 


\title{
REEF FORAMINIFERA AS BIOINDICATORS OF CORAL REEF HEALTH: LOW ISLES REEF, NORTHERN GREAT BARRIER REEF, AUSTRALIA
}

\author{
Jonathan D. Schueth* and Tracy D. Frank \\ Department of Geosciences, University of Nebraska-Lincoln, Lincoln, NE 68588-0340, USA
}

\section{ABSTRACT}

Declining water quality associated with changes in land use over the past century is considered a significant environmental threat to the health of coral platforms of the Great Barrier Reef, Australia, in particular for those situated in nearshore areas of the wet tropics. Of these reefs, perhaps the most well known is Low Isles Reef, which has been studied since 1928. Decline in scleractinian coral cover and increased abundances of soft-bodied corals and macroalgae since the 1950's have led researchers to speculate that the reef is being affected by increased nutrient and sediment fluxes from nearby rivers. The Foraminifera in Assessment and Monitoring (FORAM) Index (Hallock and others, 2003) is a numerical indicator of the suitability of water quality to support reef growth based on foraminiferal assemblages. To assess whether nutrification is an issue near Low Isles Reef, FORAM Index (FI) values were calculated from a suite of $\mathbf{5 0}$ samples collected from the reef top. Results were compared to FI values from Heron Reef, a mid-shelf platform in the southern Great Barrier Reef Province known for its lush scleractinian coral population. FI values from both reefs indicate that, overall, conditions favor coral growth. A Student's $t$ test indicates the FI values between the two reefs are similar. Principal components analysis shows that the FI values are not being constrained by water depth or depositional environment. Lower FI values, which indicate conditions unsuitable to marginal for coral growth, are restricted to particular locations on Low Isles Reef and can be explained in the context of local processes associated with the long-term geomorphological evolution of the reef. Results (1) do not support the notion that agricultural activities in nearby coastal catchments have adversely affected coral populations on Low Isles Reef and (2) demonstrate the applicability of the FI for regions outside of the western Atlantic and Caribbean, for which the index was originally created.

\section{INTRODUCTION}

Recent bleaching events and coral deaths have increased awareness of coral reef health (Wilkinson, 2000; Hallock and others, 2003). Coral communities world-wide are progressively more stressed by anthropogenic activities that are increasing the fluxes of sediment and other pollutants such as fertilizer to nearshore areas (Bryant and others, 1998). Wilkinson (2000) estimated that nearly a quarter of coral reefs have been lost due to these problems. Coral death from anthropogenic influences is a particular concern for reefs that lie within the terrigenous influence of nearby rivers. Increasing agricultural land use increases the amount

\footnotetext{
*Correspondence author. Current address: Department of Geosciences, 503 Deike Building, Pennsylvania State University, University Park, PA 16802, USA. E-mail: jschueth@geosc.psu.edu
}

of sediment, nitrogen and phosphorus transported to and accumulated in coastal oceanic waters. In the Great Barrier Reef, numerous coral communities lie within the reach of river flood plumes, potentially placing them within the influence of agricultural pollutants (Neil and Yu, 1996; Rayment and Neil, 1996).

Hallock and others (2003) developed a numerical index for relating water quality to reef health known as the Foraminifera in Reef Assessment and Monitoring Index (FORAM). The FORAM Index (FI) uses benthic foraminiferal assemblage data to quantify the suitability of an environment to support prolific growth of calcifying organisms that host algal endosymbionts (i.e., zooxanthellate corals and larger benthic foraminifera), and thus coral growth. These larger benthic foraminifera contain endosymbionts that aid in calcification and food production for the foraminifera in the same way that zooxanthallae are beneficial for coral (Hopley, 1982; Hallock, 2000). These endosymbionts limit the growth of symbiont-bearing foraminifera and coral to the photic zone and to relatively clear, nutrient-poor waters (Hallock 1999; Hallock and others, 2003). When the nutrient flux increases, the benthic community shifts to increasing dominance by fleshy algae and sponges, and the foraminiferal assemblage shifts to increasing prevalence of smaller, faster growing species. Therefore, the abundance of symbiont-bearing foraminifera should parallel coral abundance, if water quality is the major environmental control. This allows for the use of these foraminifera to quantify environmental quality with respect to coral health. Previous applications of the FI, on reefs in Florida and Puerto Rico, demonstrated the usefulness of foraminifera as bioindicators for reef condition (Hallock and others, 2003). Hallock and others (2003) suggested that the FI should be useful for reefs worldwide.

The present study applies the FI to assess nutrient impact on Low Isles Reef, a small coral platform that lies approximately $15 \mathrm{~km}$ southeast of the mouth of the Daintree River in far-north Queensland, Australia (Fig. 1). In 1928-1929, Low Isles Reef was the site of the year-long "Great Barrier Reef Expedition," a biological and geographic survey mounted by members of the Great Barrier Reef Committee and the Royal Society of London (Yonge, 1930). Survey results provided a baseline for comparison for subsequent studies of the reef (Moorhouse, 1936a, 1936b; Fairbridge and Teichert, 1947, 1948; Stephenson and others, 1958; Stoddart and others, 1978; Bell and Elmetri, 1995; Frank and Jell, 2006). Together, these works comprise a decades-long record of changes in reef ecology and morphology, making Low Isles Reef an ideal site to test if the FORAM Index can indicate whether agricultural activities in nearby coastal catchments are causing regional community changes. Results are compared to FI values from Heron Reef (Fig. 1), a larger mid-shelf 
coral platform located $85 \mathrm{~km}$ from the coast in the southern reaches of the Great Barrier Reef Province. Because a healthy and diverse population of scleractinian corals inhabits Heron Reef, its FI values are expected to reflect environmental conditions highly suitable for coral growth.

\section{BACKGROUND}

The Great Barrier Reef comprises more than 2500 coral reef buildups in a zone that extends $\sim 2300 \mathrm{~km}$ along the northeastern coast of Queensland, Australia (Hopley, 1982). Low Isles Reef is situated at $16^{\circ} 23^{\prime} \mathrm{S}, 145^{\circ} 34^{\prime} \mathrm{E}$ on the inner section of the continental shelf (Fig. 1). Especially during the summer months, river flood plumes affect Low Isles Reef and other nearby reefs because of their close proximity to the coast (Williams, 2001). Seismic profiling and vibracoring in the region show that inter-reef areas are covered by a wedge of terrigenous mud up to 20-m thick, which is dissected by paleoriver channels (Orme and others, 1978a, b; Searle and others, 1980). Muddy shelf sediments are frequently suspended by waves and longshore currents, causing turbidity in nearshore areas (Larcombe and others, 1995; Woolfe and Larcombe, 1998; Larcombe and Woolfe, 1999). These conditions differ greatly from those that prevail further offshore. On the middle to outer parts of the continental shelf, where Heron Reef is located, inter-reef sediments are dominated by calcareous skeletal sand and gravel (Maxwell, 1968; Flood and others, 1978), and the water column is generally clear.

The geomorphological features common to Low Isles Reef and other inner shelf reefs of the wet tropics include a vegetated sand cay developed via eolian deposition on the leeward end of a sandy reef flat, elongate deposits of coral shingle (cobble- to boulder-sized coral debris) along the windward margin, and a mangrove swamp (Fig. 2). Carbonate production on Low Isles Reef occurs mainly along the reef margin and shallow subtidal ponds developed in topographic lows on the reef flat that retain less than $50 \mathrm{~cm}$ of water at low spring tide (Frank and Jell, 2006). The main producer of carbonate sediment is Halimeda, which is prevalent on the reef margin, and larger benthic foraminifera, which live attached to algae in seagrass that inhabit subtidal ponds and the reef crest. Carbonate production by coralline algae and corals is confined largely to the reef margins.

Since 1928, high-energy conditions associated with cyclones and other heavy weather phenomena have generated and remobilized coarse sediment, including large fragments of coral collectively referred to as shingle. In the wake of storms, shingle is deposited in elongate, asymmetric ridges, or ramparts, along the windward margins of the reef (McLean and Stoddart, 1978). Over the years on the reef top, topographic lows that supported scleractinian coral in 1928 have been filled in by coral shingle (Frank and Jell, 2006). These ramparts restrict the flow of water into and out of the reef flat with each tidal cycle and provide a protective barrier against waves and swell. The development of a composite shingle rampart along the eastern and southeastern reef margins is credited with protecting the mangrove swamp and allowing the area of the reef top

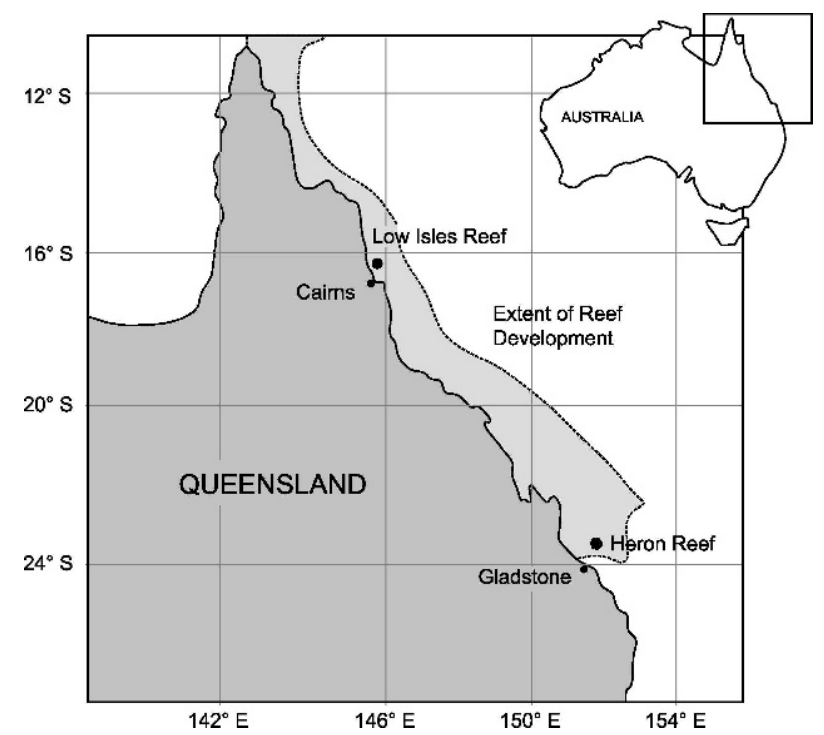

FIGURE 1. Map of northeastern Australia showing locations of Low Isles and Heron Reefs and the extent of reef development in the Great Barrier Reef system.

covered by mangroves to increase by $\sim 150 \%$ since 1928 (Frank and Jell, 2006).

A major feature unique to Low Isles Reef is the boat Anchorage, a southward-pointing, lagoon-like indentation on the northern reef margin (Fig. 2). The muddy floor of the Anchorage slopes gently away from the surrounding reef margin, reaching a maximum depth of $5 \mathrm{~m}$ at low tide. Patch reefs, composed of soft-bodied corals (Sarchophyton, Sinularia and Lobophyton) that have grown atop a hard substrate of dead scleractinian corals, are common (Bell and Elmetri, 1995). Slightly muddy sand and extensive patches of soft-bodied corals characterize the perimeter of the Anchorage. Minor disturbance of the bottom sediment by waves, currents and boat activities causes suspension of mud-sized sediment particles, causing turbid conditions. Because the surrounding reef margin is free of ramparts and other impediments to drainage (Fig. 2), the Anchorage serves as the main conduit through which water enters and exits the reef flat during each tidal cycle. Ebb tidal currents carry suspended sediment and organic debris (i.e., mangrove leaf litter and bird guano) from the reef flat and into the Anchorage (Frank and Jell, 2006).

\section{METHODS}

\section{Foraminifera in the Assessment AND Monitoring INDEX (FI)}

The FI, developed by Hallock and others (2003), involves separating foraminiferal genera into three functional groups. The first group is the "symbiont-bearing taxa," which resemble coral both by possessing endosymbionts and living in similar environments. The second group is termed the "opportunistic taxa." These foraminifera tolerate high-stress environments, especially those high in chemical pollutants or so rich in organic matter that hypoxia occurs intermittently. The third functional group is termed "other small taxa." This term is applied to all genera of small foraminifera that boom 


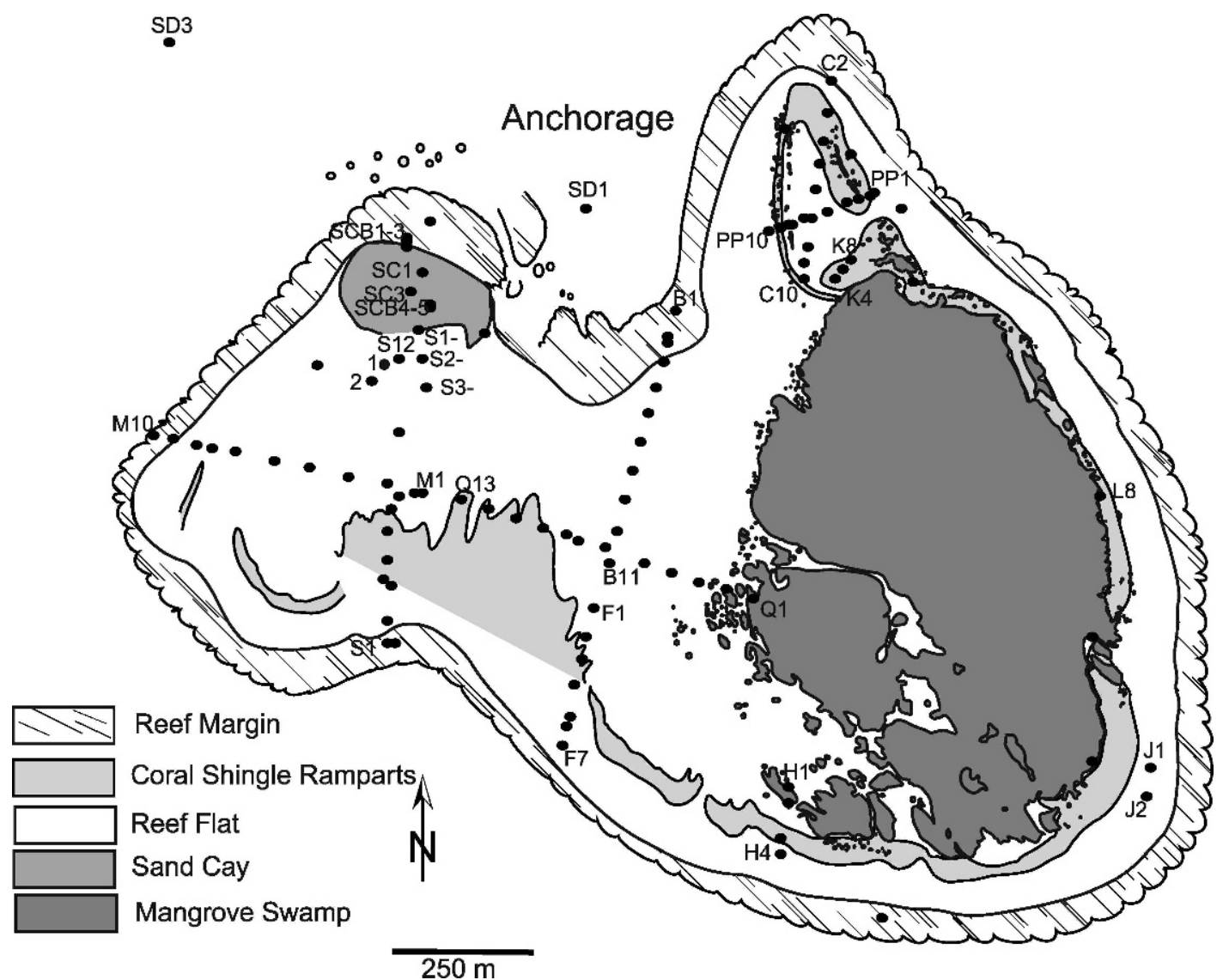

FIGURE 2. Map of Low Isles Reef showing main geomorphological features and sampling locations (after Frank and Jell, 2006).

when food supplies increase in well-oxygenated conditions. Predominance of these genera suggests water quality is marginal for coral growth. Because the calculation of the FI is based only on abundances in these functional groups, identifying rare, small taxa as "other small taxa" and placing them in the third functional group is acceptable (Hallock and others, 2003).

Foraminifera are identified to the genus level and then placed in one of the three functional groups where "s" denotes symbiont-bearing taxa, "o" represents opportunistic taxa, and "h" represents other small taxa (Hallock and others, 2003). The total number of specimens in each functional group $(N)$ is divided by the total number of specimens in the sample $(T)$ to calculate the proportion of specimens in each group $(P)$. The FI is then calculated by adding the three ratios, $P_{s}, P_{o}$ and $P_{h}$ as in the following formula:

$$
\mathrm{FI}=\left(10 \times P_{S}\right)+\left(P_{o}\right)+\left(2 \times P_{h}\right) .
$$

This index is based on an assumption that environments suitable for coral growth contain at least 25-30\% symbiontbearing foraminifera (Hallock and others, 2003). This assumption itself comes from observed trends in foraminiferal populations from the western Atlantic region, specifically Florida and Puerto Rico (Donnelly, 1993; Cockey and others, 1996; Hallock, 2000; Hallock and others, 2003). Using the above formula, the minimum FI value that corresponds to an environment that is suitable for coral growth is 4 . If there are no symbiont-bearing foraminifera, then the $P_{S}$ equals zero and the FI is less than or equal to 2 . FI values less than or equal to 2 , therefore, represent conditions that are not suitable for coral growth. It is assumed that samples that show such a low FI value correspond to locations where the environment is too stressed with nutrients and chemical pollutants to allow coral or symbiont-bearing foraminifera to grow. Values between 2 to 4 contain some (less than 25\%) symbiontbearing foraminifera. Locations where the FI values range from 2 to 4 are, therefore, defined as representing an environment in which conditions are for marginal coral growth. In such places, water quality may support living coral communities, but any damage to the coral cover will not likely be followed by recovery. Any FI value greater than 4 represents water quality suitable for coral growth, with the maximum FI value, corresponding to a $P_{s}$ value of $100 \%$, equal to 10 .

When interpreting FI values, it is important to note that the values only reflect water and sediment quality (Hallock and others, 2003). The values are not useful for detecting changes in coral populations related to factors such as abnormally high temperatures, bleaching, physical damage from storms or coral diseases. The FI cannot measure these events effectively because foraminifera do not suffer from the same diseases as corals, and they recover very quickly after bleaching events and storms. 


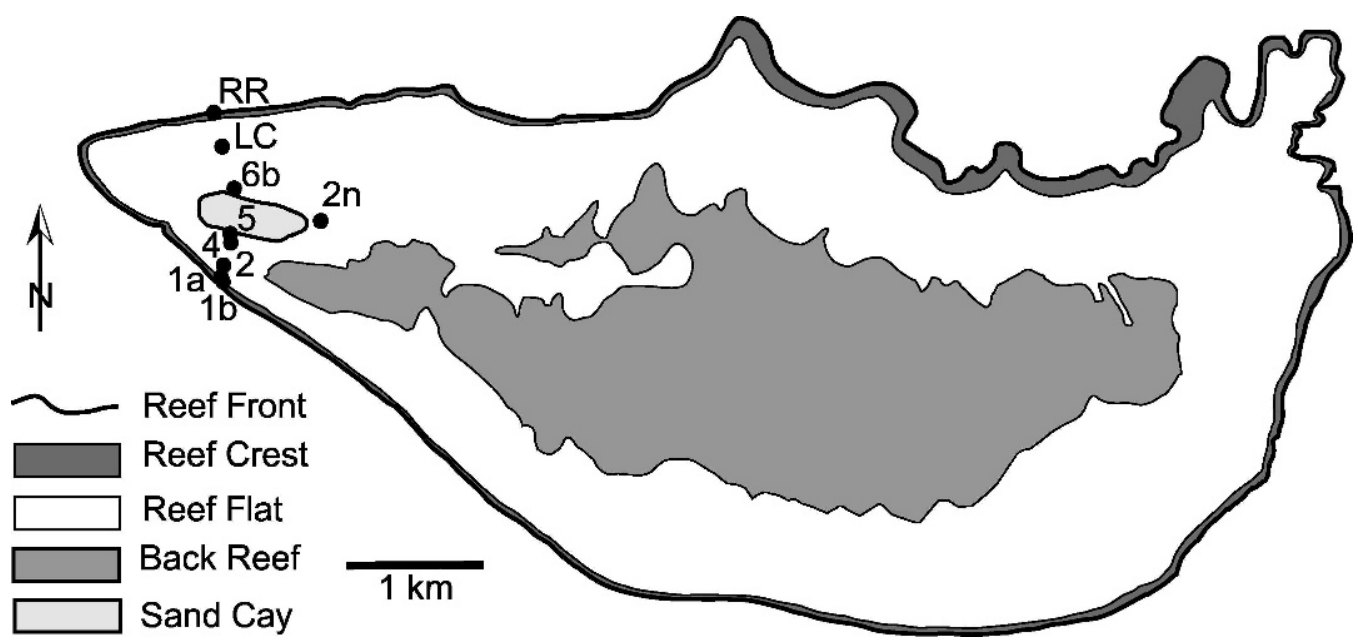

FIGURE 3. Map of Heron Reef showing main geomorphological divisions and sampling locations.

\section{SAMPLE COLLECTION}

Locations of Low Isles Reef sediment samples (50 total) are indicated on figure 2. Sediment samples from the reef top were collected on foot during low spring tides when large portions of the reef flat were either subaerially exposed or lay in water depths of less than $50 \mathrm{~cm}$. Although this situation made it difficult to obtain water depths for samples, the normal tidal range suggests that samples from the reef top experience water depths of up to $3.5 \mathrm{~m}$. Additional samples, from off-reef areas $(\sim 12 \mathrm{~m}$ depth) to the north of Low Isles Reef, were collected using a clamshell sampler deployed from a boat. To provide a basis for comparison, nine samples from Heron Reef were collected along a transect extending across the sand apron and live coral zone of the windward and leeward reef flats (Fig. 3). Sampling locations were recorded using a hand-held global positioning system (GPS) unit. On Low Isles Reef, the accuracy of GPS data to less than $\pm 2 \mathrm{~m}$ was verified using a permanent survey marker affixed to a lighthouse located on the sand cay.

\section{SAmple Preparation and ANAlysis}

Sediment samples (Figs. 2, 3) were sieved and separated into size fractions, and mean grain size and sorting were calculated (Folk, 1957). A population analysis of skeletal components was conducted by point counting 50 grains from the large to medium sand-size fractions of each sample under a stereoscope. The samples were prepared as detailed by Hallock and others (2003). A one-gram subsample was taken from each sample. These sub-samples were then studied under a stereoscope in portions of one tenth of a gram. Each foraminifera in this subsample was collected until a total of 200 was reached or all foraminifera were picked. If the one tenth of a gram sample did not contain 200 foraminifera, the process was repeated until 200 foraminifera were collected or the entire sample was picked through. In almost every case, we used the entire one-gram subsample, and therefore we are assured there was no size bias in our counts. Only fresh-looking specimens were included for analysis; foraminifera that appeared highly abraded or bioeroded, suggesting a long residence time on the reef flat, were avoided. This approach avoided preservational bias and affected only a small proportion of the total foraminifera in each sample. The abraded or bioeroded specimens consisted entirely of larger, more robust forms that are resistant to wear. Because these tend to be the symbiont-bearing forms, including them would have greatly biased our results. Individual foraminifera were then identified to the generic level. Identification was aided by descriptions of reef foraminifera from the Great Barrier Reef and elsewhere provided in Jell and others (1965), Mather and Bennet (1993), Guimerans and Currado (1999), Gandhi and others (2002) and Lobegeier (2002). Rare, small taxa that were not identified were labeled "other small taxa." Foraminifera were mounted on standard paleontology slides, and the number of each genus was counted. The foraminiferal populations were sorted into the functional groups defined by Hallock and others (2003), and the FI for each sample was calculated.

A Student's $t$ test was done to determine if the mean FI value for Heron Reef was higher than that of Low Isles Reef using PAST, a free paleontological statistical software program (http://folk.uio.no/ohammer/past/). This $t$ test was done with eight degrees of freedom (total number of Heron Reef samples minus one) and a level of significance of 0.05 .

A principal components analysis was conducted on the abundance data to investigate whether water depth and depositional environment are influencing the FI. Because the FI is based on relative abundance, any trends in the FI should reflect the abundance data. The data were first log transformed to eliminate the dominance of samples with high specimen counts. The PCA was computed using PAST with a variance-covariance cross-products matrix.

\section{RESULTS}

Results of population analyses of sediment samples in the medium sand- to gravel-size fractions are presented in Table 1. The surface sediments of both Low Isles and 
TABLE 1. Skeletal composition of sand and gravel fractions from Low Isles and Heron Reefs.

\begin{tabular}{|c|c|c|c|c|c|}
\hline Sample & $\begin{array}{l}\text { Halimeda } \\
(\%)\end{array}$ & $\begin{array}{l}\text { Coral } \\
(\%)\end{array}$ & $\begin{array}{l}\text { Mollusk } \\
(\%)\end{array}$ & $\begin{array}{c}\text { Foraminifera } \\
(\%)\end{array}$ & $\begin{array}{l}\text { Other } \\
(\%)\end{array}$ \\
\hline \multicolumn{6}{|c|}{ Low Isles Reef } \\
\hline 1 & 15.0 & 41.3 & 35.9 & 6.3 & 1.5 \\
\hline 2 & 4.1 & 64.4 & 24.1 & 3.9 & 3.4 \\
\hline B6 & 13.6 & 46.5 & 26.1 & 9.2 & 4.6 \\
\hline B9 & 5.0 & 63.6 & 19.5 & 1.5 & 10.5 \\
\hline B10 & 8.0 & 62.6 & 22.2 & 3.3 & 3.8 \\
\hline B11 & 13.3 & 43.2 & 19.8 & 18.9 & 4.7 \\
\hline $\mathrm{C} 4$ & 9.8 & 51.9 & 22.5 & 10.9 & 4.9 \\
\hline C9 & 13.1 & 37.6 & 30.9 & 12.7 & 5.6 \\
\hline $\mathrm{F} 2$ & 5.9 & 68.1 & 16.5 & 8.8 & 0.7 \\
\hline F3 & 8.6 & 23.3 & 32.6 & 31.8 & 3.7 \\
\hline $\mathrm{F} 4$ & 9.6 & 50.7 & 13.8 & 25.2 & 0.8 \\
\hline F5 & 8.7 & 58.2 & 14.6 & 17.2 & 1.4 \\
\hline F7 & 8.5 & 38.0 & 37.8 & 13.8 & 1.8 \\
\hline H1 & 7.9 & 31.1 & 31.7 & 20.6 & 8.7 \\
\hline $\mathrm{H} 2$ & 0.0 & 58.0 & 8.0 & 34.0 & 0.0 \\
\hline $\mathrm{J} 1$ & 0.3 & 57.6 & 24.5 & 13.1 & 4.5 \\
\hline $\mathrm{J} 2$ & 0.0 & 58.0 & 23.7 & 10.2 & 8.1 \\
\hline K4 & 23.4 & 26.9 & 21.5 & 25.5 & 2.6 \\
\hline K8 & 0.9 & 58.0 & 24.8 & 13.5 & 2.8 \\
\hline L8 & 0.0 & 67.9 & 30.4 & 0.0 & 1.8 \\
\hline M1 & 32.5 & 29.6 & 26.2 & 11.0 & 0.7 \\
\hline M2 & 28.0 & 29.6 & 30.3 & 9.8 & 2.3 \\
\hline M3 & 20.2 & 28.4 & 29.3 & 8.3 & 13.7 \\
\hline M4 & 18.4 & 32.5 & 30.6 & 16.3 & 2.2 \\
\hline M6 & 11.2 & 48.4 & 26.8 & 10.9 & 2.7 \\
\hline M8 & 8.5 & 39.1 & 38.8 & 9.7 & 3.9 \\
\hline M10 & 10.4 & 32.6 & 28.5 & 19.8 & 8.7 \\
\hline PP5 & 6.9 & 37.5 & 31.5 & 17.4 & 6.7 \\
\hline PP7 & 4.9 & 49.5 & 30.7 & 8.3 & 6.6 \\
\hline PP9 & 16.0 & 18.0 & 44.0 & 12.0 & 10.0 \\
\hline PP10 & 7.8 & 55.7 & 28.2 & 4.7 & 3.6 \\
\hline Q2 & 7.0 & 42.5 & 36.5 & 11.1 & 3.1 \\
\hline Q3 & 2.6 & 50.8 & 34.1 & 9.0 & 3.4 \\
\hline Q4 & 6.5 & 58.1 & 19.9 & 11.7 & 3.8 \\
\hline Q9 & 21.4 & 48.7 & 15.8 & 12.6 & 1.4 \\
\hline Q12 & 31.2 & 33.4 & 20.8 & 13.0 & 1.6 \\
\hline S2- & 4.4 & 63.1 & 24.9 & 1.6 & 6.0 \\
\hline S3- & 3.4 & 45.5 & 26.6 & 16.6 & 7.9 \\
\hline S3 & 16.5 & 48.4 & 25.5 & 7.0 & 2.5 \\
\hline S4 & 5.8 & 70.0 & 21.2 & 1.0 & 2.0 \\
\hline S6 & 32.6 & 19.7 & 24.8 & 20.0 & 2.9 \\
\hline S8 & 26.6 & 43.4 & 15.3 & 10.4 & 4.3 \\
\hline S9 & 20.7 & 39.7 & 27.0 & 10.0 & 2.6 \\
\hline $\mathrm{SC} 2$ & 1.4 & 46.9 & 30.6 & 14.5 & 6.6 \\
\hline SC3 & 1.7 & 38.3 & 40.4 & 9.3 & 10.3 \\
\hline SCB1 & 3.1 & 17.6 & 52.0 & 14.5 & 12.8 \\
\hline SCB2 & 4.5 & 47.4 & 30.1 & 14.3 & 3.7 \\
\hline SCB5 & 4.7 & 43.2 & 35.9 & 9.2 & 7.0 \\
\hline SDlb & 9.7 & 10.7 & 47.4 & 19.5 & 12.8 \\
\hline SD3 & 2.7 & 33.2 & 52.8 & 4.4 & 6.8 \\
\hline \multicolumn{6}{|c|}{ Heron Reef } \\
\hline $2 \mathrm{n}$ & 1.0 & 78.0 & 16.0 & 5.0 & 0.0 \\
\hline $\mathrm{LC}$ & 12.0 & 52.0 & 16.0 & 19.0 & 0.0 \\
\hline RR & 5.0 & 72.0 & 19.0 & 3.0 & 0.0 \\
\hline $6 \mathrm{~b}$ & 7.0 & 69.1 & 18.8 & 5.1 & 0.0 \\
\hline $1 \mathrm{~b}$ & 0.0 & 81.2 & 18.3 & 0.1 & 0.0 \\
\hline 1a & 2.3 & 65.0 & 27.0 & 2.2 & 0.0 \\
\hline 2 & 2.8 & 62.7 & 31.3 & 0.9 & 0.0 \\
\hline 4 & 27.1 & 37.0 & 23.4 & 9.6 & 0.0 \\
\hline 5 & 1.8 & 60.1 & 32.7 & 4.4 & 0.0 \\
\hline
\end{tabular}

Heron Reefs are dominated by coral, with coral fragments composing $45 \%$ of Low Isles and $63 \%$ of Heron Reef sediments. The second most abundant component on both reefs is mollusk shells, which compose $20-30 \%$ of the sediment. On average, foraminifera make up $5-10 \%$ of the sediment on both reefs (Table 2).

On both reefs, each functional group is dominated by the same set of genera. In the symbiont-bearing group, the most common genera are Calcarina, Amphistegina, Marginopora, Baculogypsina, Peneroplis and Heterostegina. The genus Calcarina is characterized by spherical epiphytic foraminifera with a hispid test and several spines (Jell and others, 1965; Lobegeier, 2002), the most common on Heron and Low Isles Reefs being $C$. mayori and $C$. spengleri. Amphistegina is represented in great abundance by the epiphytic A. lessonii. Baculogypsina is also a very common epiphytic form represented by $B$. sphaerulata and often is found in association with Calcarina spengleri on the reef flat (Jell and others, 1965; Lobegeier, 2002). Marginopora is a large, disc-shaped epiphytic foraminifera found in almost all samples from Heron and Low Isles Reefs. Specimens of Peneroplis and Heterostegina are rarer among the symbiont-bearing genera, and their identification was based on descriptions from Jell and others (1965). Genera most common in the opportunistic taxa functional group are Elphidium, Epistomoroides, Planorbulina-included here because this genus is often found in muddy water with abundant vegetation cover (Guimerans and Currado, 1999)_Pararotalia and Brizalina. The genera in the "other small taxa" group are Quinqueloculina, Triloculina, Miliolinella and Spiroloculina, as well as rare occurrences of Globigerina, Cornuspira, Textularia and other small forms that are very rare and which we have termed "other small taxa." Planktonic foraminifera were included in the anaylsis because when their population blooms, they can stress symbiont-bearing taxa in ways similar to the benthic taxa.

The calculated FI values are shown in Table 3 and figure 4. Most samples ( $81 \%$ of Low Isles Reef samples, $\mathrm{n}=50 ; 89 \%$ of Heron samples, $\mathrm{n}=9$ ) are characterized by FI values greater than 4.0, implying that water quality on both reefs is suitable for coral growth (Hallock and others, 2003). FI values of less than 2.0, indicating conditions not suitable for coral growth, are only found at Low Isles Reef sites in or near the Anchorage (less than $1 \%$ of the total samples). FI values on Low Isles Reef range from $\sim 1.8-10.0$. The highest FI values are focused in the southwestern portion and windward edge of the reef (Fig. 4). FI values less than 4.0 occur in the Anchorage and in the southeastern part of the reef flat. On Heron Reef, FI values range from $\sim 3.2$ to 9.0 , with only one sample falling below 4.0. The FI values increase toward the zone of live coral cover at the reef margin.

The calculated $t$ value for the Heron and Low Isles Reef samples was 0.942 . The $t$ value, corresponding to eight degrees of freedom and a level of significance of 0.05 , is 1.60 , and because our calculated value is lower, we cannot reject the hypothesis that the mean FI value for Heron Reef is less than or equal to the mean value for Low Isles Reef. Therefore, nothing in our data suggests the mean FI value for Heron Reef is higher than that of Low Isles Reef.

The results of the PCA are shown in figure 5. There are two main variables that describe the data set (PC1 with $50 \%$ of the data variance and PC2 with 26\%). Five depositional environments are indicated in the plot: anchorage, reef flat, shingle ramparts, sand cay and reef rim plus reef crest. 
TABLE 2. Counts of foraminiferal genera from Low Isles and Heron Reefs.

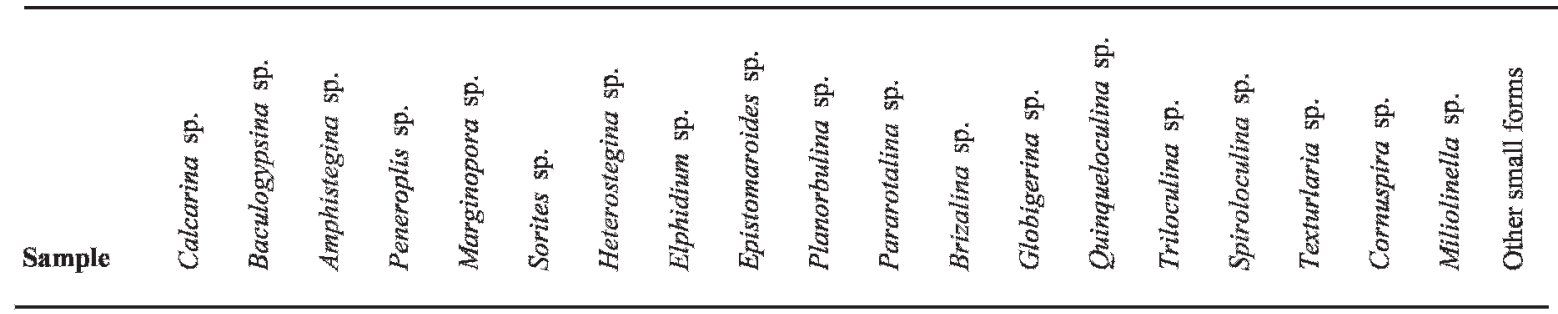

\begin{tabular}{|c|c|c|c|c|c|c|c|c|c|c|c|c|c|c|c|c|c|c|c|c|}
\hline \multicolumn{21}{|c|}{ Low Isles Reef } \\
\hline 1 & 2 & 3 & 3 & 0 & 3 & 0 & 1 & 0 & 0 & 0 & 1 & 0 & 0 & 0 & 0 & 0 & 0 & 0 & 0 & 1 \\
\hline 2 & 0 & 0 & 3 & 1 & 0 & 0 & 0 & 2 & 1 & 0 & 0 & 1 & 0 & 1 & 4 & 0 & 0 & 0 & 0 & 0 \\
\hline B10 & 0 & 0 & 1 & 36 & 6 & 0 & 0 & 4 & 20 & 18 & 3 & 3 & 0 & 36 & 35 & 4 & 0 & 0 & 0 & 0 \\
\hline B11 & 1 & 0 & 3 & 11 & 10 & 1 & 0 & 25 & 20 & 13 & 1 & 1 & 0 & 52 & 30 & 3 & 1 & 0 & 0 & 1 \\
\hline B6 & 0 & 0 & 3 & 13 & 7 & 0 & 0 & 29 & 5 & 8 & 8 & 0 & 0 & 31 & 33 & 0 & 0 & 0 & 0 & 0 \\
\hline B9 & 0 & 0 & 0 & 2 & 0 & 1 & 0 & 28 & 14 & 13 & 2 & 1 & 0 & 26 & 26 & 4 & 0 & 1 & 0 & 0 \\
\hline $\mathrm{C4}$ & 11 & 9 & 7 & 7 & 14 & 5 & 0 & 6 & 12 & 5 & 5 & 1 & 0 & 8 & 8 & 5 & 0 & 1 & 0 & 2 \\
\hline $\mathrm{Cg}$ & 6 & 0 & 4 & 3 & 20 & 0 & 0 & 0 & 5 & 6 & 0 & 1 & 0 & 4 & 1 & 0 & 0 & 0 & 0 & 0 \\
\hline F2 & 6 & 1 & 4 & 1 & 12 & 1 & 0 & 0 & 0 & 3 & 0 & 1 & 0 & 0 & 2 & 0 & 0 & 0 & 0 & 0 \\
\hline F3 & 32 & 7 & 13 & 0 & 10 & 0 & 0 & 0 & 0 & 0 & 0 & 0 & 0 & 0 & 0 & 0 & 0 & 0 & 0 & 0 \\
\hline F4 & 16 & 8 & 14 & 0 & 9 & 1 & 1 & 0 & 0 & 0 & 0 & 0 & 0 & 0 & 0 & 0 & 0 & 0 & 0 & 1 \\
\hline F5 & 70 & 35 & 19 & 7 & 20 & 0 & 0 & 2 & 0 & 2 & 1 & 0 & 0 & 1 & 2 & 0 & 0 & 0 & 0 & 0 \\
\hline F7 & 34 & 45 & 12 & 0 & 1 & 0 & 0 & 1 & 0 & 0 & 0 & 1 & 1 & 0 & 0 & 0 & 0 & 0 & 0 & 2 \\
\hline $\mathrm{Hl}$ & 1 & 1 & 5 & 8 & 5 & 0 & 0 & 2 & 7 & 4 & 1 & 0 & 0 & 3 & 8 & 0 & 0 & 0 & 0 & 3 \\
\hline $\mathrm{H} 2$ & 0 & 0 & 3 & 11 & 14 & 3 & 0 & 5 & 9 & 17 & 3 & 1 & 0 & 8 & 23 & 2 & 0 & 1 & 0 & 0 \\
\hline J1 & 0 & 4 & 7 & 0 & 0 & 0 & 0 & 14 & 7 & 6 & 0 & 0 & 0 & 2 & 6 & 0 & 0 & 1 & 0 & 0 \\
\hline $\mathrm{J} 2$ & 0 & 2 & 1 & 0 & 0 & 0 & 0 & 0 & 0 & 0 & 0 & 0 & 0 & 0 & 0 & 0 & 0 & 0 & 0 & 0 \\
\hline K4 & 0 & 0 & 2 & 5 & 29 & 0 & 0 & 5 & 0 & 1 & 0 & 0 & 0 & 10 & 1 & 0 & 0 & 0 & 0 & 0 \\
\hline $\mathrm{K} 8$ & 3 & 8 & 3 & 0 & 2 & 0 & 0 & 0 & 0 & 0 & 0 & 0 & 0 & 0 & 0 & 0 & 0 & 0 & 0 & 0 \\
\hline L8 & 4 & 27 & 2 & 0 & 0 & 0 & 0 & 0 & 0 & 0 & 0 & 0 & 0 & 0 & 0 & 0 & 0 & 0 & 0 & 1 \\
\hline M1 & 2 & 0 & 6 & 1 & 11 & 0 & 0 & 1 & 3 & 0 & 0 & 2 & 0 & 14 & 0 & 0 & 0 & 0 & 0 & 2 \\
\hline M10 & 24 & 14 & 18 & 0 & 2 & 0 & 0 & 1 & 0 & 0 & 0 & 0 & 0 & 0 & 0 & 0 & 0 & 0 & 2 & 1 \\
\hline M2 & 1 & 1 & 8 & 0 & 13 & 0 & 0 & 0 & 0 & 0 & 0 & 0 & 0 & 0 & 0 & 0 & 0 & 0 & 3 & 2 \\
\hline M3 & 0 & 0 & 6 & 8 & 18 & 0 & 0 & 7 & 3 & 1 & 0 & 1 & 0 & 3 & 8 & 1 & 0 & 0 & 4 & 4 \\
\hline M4 & 8 & 0 & 9 & 3 & 17 & 1 & 0 & 8 & 0 & 1 & 1 & 0 & 0 & 1 & 6 & 0 & 0 & 0 & 0 & 2 \\
\hline M6 & 1 & 0 & 4 & 5 & 4 & 6 & 0 & 0 & 2 & 3 & 1 & 0 & 0 & 1 & 9 & 3 & 0 & 0 & 0 & 2 \\
\hline M8 & 1 & 0 & 7 & 0 & 6 & 0 & 0 & 1 & 1 & 0 & 0 & 0 & 0 & 0 & 0 & 0 & 0 & 0 & 5 & 2 \\
\hline PP10 & 6 & 5 & 14 & 2 & 2 & 6 & 1 & 5 & 6 & 3 & 1 & 1 & 2 & 13 & 5 & 0 & 0 & 1 & 14 & 1 \\
\hline PP5 & 2 & 0 & 8 & 0 & 16 & 1 & 2 & 21 & 10 & 7 & 0 & 1 & 0 & 5 & 19 & 0 & 0 & 1 & 0 & 0 \\
\hline PP7 & 0 & 1 & 5 & 0 & 6 & 1 & 0 & 1 & 2 & 0 & 0 & 0 & 0 & 0 & 0 & 0 & 0 & 0 & 0 & 0 \\
\hline PP9 & 6 & 22 & 4 & 0 & 12 & 0 & 0 & 0 & 0 & 0 & 0 & 0 & 0 & 0 & 0 & 0 & 0 & 0 & 0 & 0 \\
\hline Q12 & 3 & 0 & 9 & 12 & 16 & 0 & 0 & 3 & 6 & 6 & 3 & 1 & 0 & 3 & 9 & 1 & 1 & 0 & 1 & 1 \\
\hline $\mathrm{Q} 2$ & 0 & 0 & 1 & 2 & 12 & 0 & 0 & 0 & 2 & 0 & 1 & 0 & 0 & 12 & 5 & 1 & 0 & 1 & 0 & 0 \\
\hline Q3 & 0 & 0 & 0 & 0 & 6 & 1 & 0 & 1 & 2 & 0 & 0 & 0 & 0 & 1 & 5 & 0 & 0 & 0 & 0 & 0 \\
\hline Q4 & 0 & 0 & 1 & 5 & 7 & 3 & 0 & 2 & 1 & 2 & 0 & 0 & 0 & 5 & 4 & 0 & 0 & 0 & 0 & 0 \\
\hline Q9 & 23 & 13 & 10 & 2 & 15 & 2 & 0 & 6 & 1 & 3 & 3 & 0 & 0 & 3 & 1 & 1 & 0 & 0 & 0 & 0 \\
\hline
\end{tabular}

There is noticeable separation between the anchorage samples and samples from the sand cay, shingle ramparts and reef rim. However, reef flat samples span the entire plot, and the only separation appears to be based on samples with low FI values and those with higher FI values. This indicates that depositional environment is not controlling FI values. Deeper water Anchorage samples are similar to many reef flat samples, despite difference in water depth. Likewise, high-energy samples (such as the shingle rampart samples) are similar to some low-energy reef flat samples. This suggests that the
FI values are not constrained by either water depth or energy.

\section{DISCUSSION}

Despite significant differences in proximity to the coast and the degree to which sites are influenced by terrigenous sedimentation, both Low Isles and Heron Reefs are characterized, as shown through the $t$ test, by a similar range of FI values. The majority of FI values are greater than 4 , suggesting that general water quality in both regions 
TABle 2. Continued.

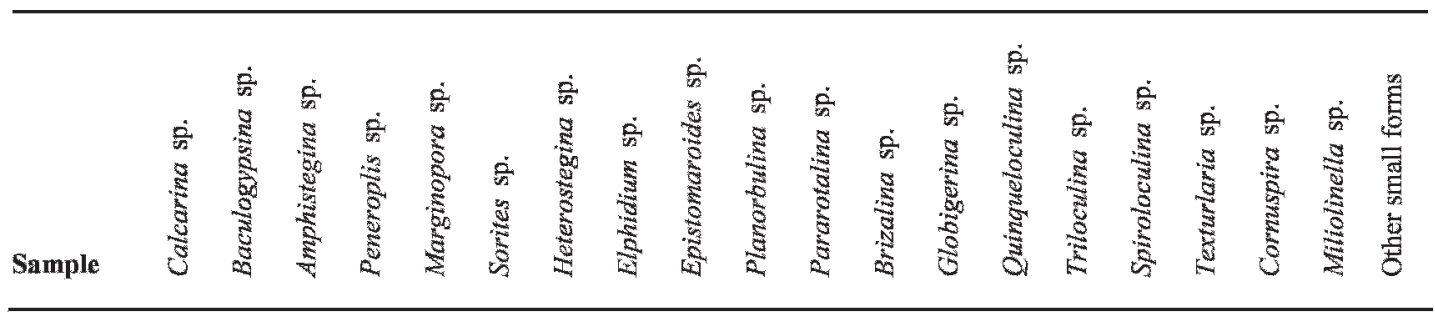

\begin{tabular}{|c|c|c|c|c|c|c|c|c|c|c|c|c|c|c|c|c|c|c|c|}
\hline \multicolumn{20}{|c|}{ Low Istes Reef (cont.) } \\
\hline S2- & 0 & 0 & 5 & 4 & 2 & 1 & 0 & 14 & 1 & 18 & 5 & 5 & 0 & 24 & 25 & 4 & 0 & 3 & 0 \\
\hline \$3 & 9 & 9 & 11 & 7 & 8 & 0 & 0 & 1 & 1 & 3 & 4 & 0 & 0 & 2 & 5 & 0 & 0 & 0 & 0 \\
\hline S3- & 0 & 0 & 0 & 0 & 4 & 0 & 0 & 0 & 0 & 0 & 0 & 0 & 0 & 0 & 0 & 0 & 0 & 0 & 2 \\
\hline$\$ 4$ & 22 & 10 & 21 & 5 & 3 & 0 & 2 & 4 & 0 & 2 & 3 & 0 & 0 & 3 & 1 & 0 & 0 & 0 & 0 \\
\hline S6 & 16 & 14 & 28 & 0 & 2 & 1 & 0 & 1 & 1 & 1 & 0 & 0 & 0 & 0 & 0 & 0 & 0 & 0 & 1 \\
\hline S8 & 15 & 2 & 23 & 1 & 11 & 1 & 0 & 8 & 2 & 1 & 0 & 0 & 0 & 0 & 7 & 0 & 0 & 0 & 0 \\
\hline$\$ 9$ & 2 & 0 & 12 & 3 & 11 & 0 & 0 & 5 & 2 & 3 & 0 & 0 & 0 & 0 & 3 & 0 & 0 & 0 & 0 \\
\hline $\mathrm{SC}_{2}$ & 1 & 0 & 6 & 0 & 0 & 0 & 0 & 2 & 0 & 0 & 0 & 0 & 0 & 0 & 0 & 0 & 0 & 0 & 0 \\
\hline $\mathrm{SC} 3$ & 0 & 0 & 5 & 0 & 0 & 1 & 0 & 1 & 0 & 0 & 0 & 0 & 0 & 0 & 0 & 0 & 0 & 0 & 0 \\
\hline SCB 1 & 1 & 0 & 16 & 0 & 1 & 0 & 0 & 1 & 0 & 0 & 0 & 0 & 0 & 0 & 0 & 0 & 0 & 0 & 0 \\
\hline $\mathrm{SCB} 2$ & 3 & 4 & 5 & 0 & 2 & 0 & 0 & 1 & 0 & 0 & 0 & 0 & 0 & 0 & 0 & 0 & 0 & 0 & 0 \\
\hline SCB5 & 1 & 1 & 8 & 0 & 3 & 0 & 0 & 0 & 0 & 0 & 0 & 0 & 0 & 0 & 0 & 0 & 0 & 0 & 7 \\
\hline SDIb & 0 & 0 & 0 & 3 & 0 & 2 & 0 & 19 & 15 & 11 & 0 & 9 & 3 & 55 & 56 & 0 & 0 & 4 & 0 \\
\hline SD3 & 0 & 0 & 4 & 0 & 0 & 0 & 0 & 36 & 22 & 0 & 1 & 16 & 3 & 27 & 37 & 1 & 0 & 1 & 0 \\
\hline
\end{tabular}

\begin{tabular}{|c|c|c|c|c|c|c|c|c|c|c|c|c|c|c|c|c|c|c|c|c|}
\hline \multicolumn{21}{|c|}{ Heron Reef } \\
\hline $2 n$ & 4 & 1 & 3 & 0 & 4 & 0 & 0 & 11 & 0 & 3 & 2 & 1 & 1 & 18 & 16 & 0 & 0 & 0 & 1 & 1 \\
\hline $\mathrm{LC}$ & 55 & 17 & 6 & 8 & 6 & 0 & 0 & 0 & 1 & 1 & 1 & 0 & 0 & 5 & 0 & 0 & 0 & 0 & 0 & 0 \\
\hline RR & 2 & 0 & 2 & 0 & 2 & 0 & 0 & 0 & 0 & 1 & 0 & 0 & 0 & 0 & 1 & 0 & 0 & 0 & 0 & 1 \\
\hline $6 b$ & 5 & 0 & 0 & 0 & 2 & 0 & 0 & 1 & 0 & 3 & 1 & 0 & 0 & 1 & 1 & 0 & 0 & 0 & 0 & 0 \\
\hline $1 b$ & 5 & 2 & 2 & 0 & 3 & 0 & 0 & 0 & 0 & 0 & 1 & 0 & 0 & 2 & 0 & 0 & 1 & 0 & 0 & 0 \\
\hline $1 \mathrm{a}$ & 1 & 1 & 0 & 0 & 3 & 0 & 0 & 0 & 0 & 1 & 1 & 0 & 0 & 1 & 0 & 0 & 0 & 0 & 0 & 0 \\
\hline 2 & 6 & 0 & 2 & 5 & 2 & 2 & 2 & 2 & 0 & 2 & 0 & 0 & 2 & 4 & 2 & 0 & 0 & 0 & 0 & 1 \\
\hline 4 & 20 & 1 & 4 & 3 & 1 & 8 & 0 & 5 & 0 & 4 & 8 & 2 & 1 & 12 & 3 & 0 & 0 & 0 & 0 & 0 \\
\hline 5 & 3 & 0 & 0 & 0 & 1 & 0 & 0 & 3 & 0 & 1 & 0 & 0 & 0 & 5 & 0 & 0 & 0 & 0 & 0 & 0 \\
\hline
\end{tabular}

is favorable for coral growth. As such, should coral communities in these areas of the Great Barrier Reef suffer damage from storms or bleaching events, recovery can be expected at windward sites. Water quality near Low Isles Reef appears to have not been significantly impacted by increased fluxes of sediment, nutrients and other pollutants to coastal areas (Bell, 1991, 1992) related to changing land use over the past century (Neil and Yu, 1996; Rayment and Neil, 1996). Rather, results are consistent with studies of sediment transport (Orpin and others, 1999; Larcombe and Woolfe, 1999; Larcombe and Carter, 2004), which suggest that a strong northwesterly current along the shoreface and inner shelf that is maintained by the prevailing southeasterly winds inhibits the dispersal of terrigenous sediment across the shelf (Hopley, 1982).

On Low Isles Reef, FI values $>4$, suggesting conditions favorable for coral growth, occur along much of the windward periphery (eastern and southern margins) and across the western half of the reef flat (Fig. 4). Some values, however, should be treated with caution. For example, very high values determined on samples from the vegetated sand cay on the northwestern edge of the reef flat reflect the sorting actions of wind in depositing medium sand-sized Calcarina and Amphistegina tests. The results of the PCA, however, suggest that while wind deposition may be biasing some samples, factors such as water depth and depositional environment are having little to no effect on the FI results. Because the water depth in our study differs by $20 \mathrm{~m}$ from Hallock and others (2003), it is possible that the FI is invalid in our study area. However, because the PCA indicates water depth is not influencing our results, it seems unlikely that this difference in water depth should invalidate our results.

Marginal $(\mathrm{FI}=2-4)$ to unsuitable $(\mathrm{FI}<2)$ conditions for coral growth were indicated in nine samples from Low Isles Reef. These lower FI values cluster in the Anchorage and areas of reef flat directly adjacent to the mangrove swamp (Fig. 5). The lower FI values coincide with areas of the reef top that are dominated by soft-bodied corals and macroalgae, and where scleractinian corals are in low abundance (Stephenson and others, 1958; Bell and Elmetri, 1995; Frank and Jell, 2006). 
TABLE 3. FI (FORAM Index) values for both Heron and Low Isles Reefs. GPS coordinates, where X and Y are GPS coordinates as referenced to AGS 84, are shown for Low Isles Reef.

\begin{tabular}{|c|c|c|c|}
\hline Sample & $\mathrm{X}$ & $\mathrm{Y}$ & FI \\
\hline \multicolumn{4}{|c|}{ Low Isles Reef } \\
\hline 1 & 346023 & 187722 & 9.3 \\
\hline 2 & 346009 & 187685 & 4.2 \\
\hline B6 & 346501 & 187627 & 3.0 \\
\hline B9 & 346460 & 187480 & 1.7 \\
\hline B10 & 346444 & 187425 & 3.7 \\
\hline B11 & 346429 & 187369 & 2.9 \\
\hline $\mathrm{C} 4$ & 346812 & 188103 & 5.6 \\
\hline C9 & 346780 & 187889 & 6.8 \\
\hline $\mathrm{F} 2$ & 346388 & 187238 & 8.3 \\
\hline F3 & 346380 & 187201 & 10.0 \\
\hline $\mathrm{F} 4$ & 346370 & 187154 & 10.0 \\
\hline F5 & 346358 & 187103 & 9.5 \\
\hline F7 & 346346 & 187051 & 9.7 \\
\hline H1 & 346751 & 186980 & 5.0 \\
\hline $\mathrm{H} 2$ & 346747 & 186949 & 4.0 \\
\hline $\mathrm{J} 1$ & 347397 & 187011 & 3.3 \\
\hline $\mathrm{J} 2$ & 347390 & 186963 & 10.0 \\
\hline $\mathrm{K} 4$ & 346836 & 187863 & 7.2 \\
\hline K8 & 346858 & 187894 & 10.0 \\
\hline L8 & 347307 & 187483 & 10.0 \\
\hline M1 & 346101 & 187490 & 5.6 \\
\hline M2 & 346034 & 187504 & 10.0 \\
\hline M3 & 345967 & 187518 & 6.4 \\
\hline M4 & 345899 & 187532 & 7.2 \\
\hline M6 & 345764 & 187560 & 5.9 \\
\hline M8 & 345697 & 187574 & 8.9 \\
\hline M10 & 345616 & 187591 & 9.8 \\
\hline PP5 & 346822 & 187980 & 4.1 \\
\hline PP7 & 346759 & 187957 & 8.3 \\
\hline PP9 & 346738 & 187950 & 10.0 \\
\hline PP10 & 346717 & 187942 & 5.6 \\
\hline Q2 & 346638 & 187320 & 5.2 \\
\hline Q3 & 346589 & 187336 & 5.3 \\
\hline Q4 & 346540 & 18353 & 5.8 \\
\hline Q9 & 346355 & 187415 & 8.0 \\
\hline Q12 & 346218 & 187460 & 6.0 \\
\hline S2- & 346099 & 187724 & 2.5 \\
\hline S3- & 346104 & 187674 & 10.0 \\
\hline S3 & 346046 & 187230 & 7.7 \\
\hline S4 & 346045 & 187329 & 8.4 \\
\hline S6 & 346033 & 187372 & 9.6 \\
\hline S8 & 346044 & 187464 & 7.7 \\
\hline S9 & 346057 & 187486 & 7.1 \\
\hline $\mathrm{SC} 2$ & 346097 & 187872 & 8.0 \\
\hline $\mathrm{SC} 3$ & 346076 & 187839 & 8.7 \\
\hline SCB1 & 346069 & 187919 & 9.5 \\
\hline SCB2 & 346069 & 187926 & 9.4 \\
\hline SCB5 & 346110 & 187812 & 10.0 \\
\hline SD1b & 346392 & 187984 & 1.9 \\
\hline SD3 & 345646 & 188270 & 1.7 \\
\hline \multicolumn{4}{|l|}{ Heron Reef } \\
\hline $2 n$ & & & 3.2 \\
\hline LC & & & 9.3 \\
\hline $\mathrm{RR}$ & & & 7.2 \\
\hline $6 b$ & & & 5.6 \\
\hline $1 \mathrm{~b}$ & & & 7.9 \\
\hline $1 \mathrm{a}$ & & & 6.8 \\
\hline 2 & & & 6.6 \\
\hline 4 & & & 5.8 \\
\hline 5 & & & 4.2 \\
\hline
\end{tabular}

The distribution of FI values across Low Isles Reef top mimics the distribution of viable hard-bodied coral communities. Several studies have reported on the effects of cyclone damage on Low Isles Reef, with breakage of scleractinian coral, especially Acropora, particularly prevalent along the windward margins. In the wake of a 1934 cyclone, Moorhouse (1936b) described "mutilation, even decimation" of coral in areas where flourishing colonies had previously existed on windward margins, with "a few straggling colonies" of Acropora surviving in the lee of large boulders on the northwestern margin. Stephenson and others (1958) performed an ecological survey in 1954 to evaluate damage from a cyclone that struck the reef in 1950 and to note any other changes that had occurred since the 1928 survey (Stephenson and others, 1931; Manton and Stephenson, 1935). Although coral damage from the cyclone was still evident, Stephenson and others (1958) reported survival of most massive corals and significant recovery of more fragile corals (i.e., Acropora and Montipora), and characterized changes in coral populations on the windward margins since 1928 as slight. The high FI values derived from sites along the windward periphery thus accurately reflect a healthy coral population, which has been able to recover from past cyclone damage and should be able recover from future events.

While coral communities on the windward periphery of Low Isles Reef have remained largely unchanged since 1928 (Stephenson and others, 1958; Frank and Jell, 2006), populations on the leeward margin have changed significantly (Stephenson and others, 1958; Bell and Elmetri, 1995). The most striking changes have occurred in patch reefs that lie within and surround the Anchorage. Reports from the initial expedition to Low Isles Reef indicate that in 1928 scleractinian corals, including massive (e.g., Porites, Favites, Monastria and Goniastria) and branching or digitate (e.g., Acropora) forms, dominated the patch reefs and margins of the Anchorage (Manton and Stephenson, 1935). These communities suffered significant physical damage in the 1934 cyclone (Moorhouse, 1936b). Fairbridge and Teichert (1948), however, noted that, by 1945 , patch reefs in the Anchorage had "grown a recognizable amount" since 1928, suggesting recovery within a decade of the cyclone. Coral communities in the Anchorage were again damaged by a cyclone in 1950, which was unusual in that it approached Low Isles Reef from the north to northeast and hit what is normally the lee side of the reef. A survey of Anchorage benthos in 1954 indicated that live hard coral was sparse and that dead scleractinian coral was being overgrown by faster-growing soft-bodied coral (Stephenson and others, 1958). Subsequent observations by Bell and Elmetri (1995) and Frank and Jell (2006) indicate that the margins and patch reefs of the Anchorage are now dominated by noncalcareous macroalgae and softbodied corals.

The changes in coral populations in the Anchorage of Low Isles Reef have been attributed to both regional (Bell and Elmetri, 1995) and local (Stephenson and others, 1958; Frank and Jell, 2006) factors. Stephenson and others (1958) suggested that the scleractinian corals were outpaced by faster-growing soft-bodied corals and macroalgae, which took over the available substrate in the wake of the storm. However, the lack of recovery some 40 years later (Bell and Elmetri, 1995) and the fact that macroalgae and soft-bodied corals respond favorably to increased nutrient levels suggest that the community changes reflect nutrification. Some 


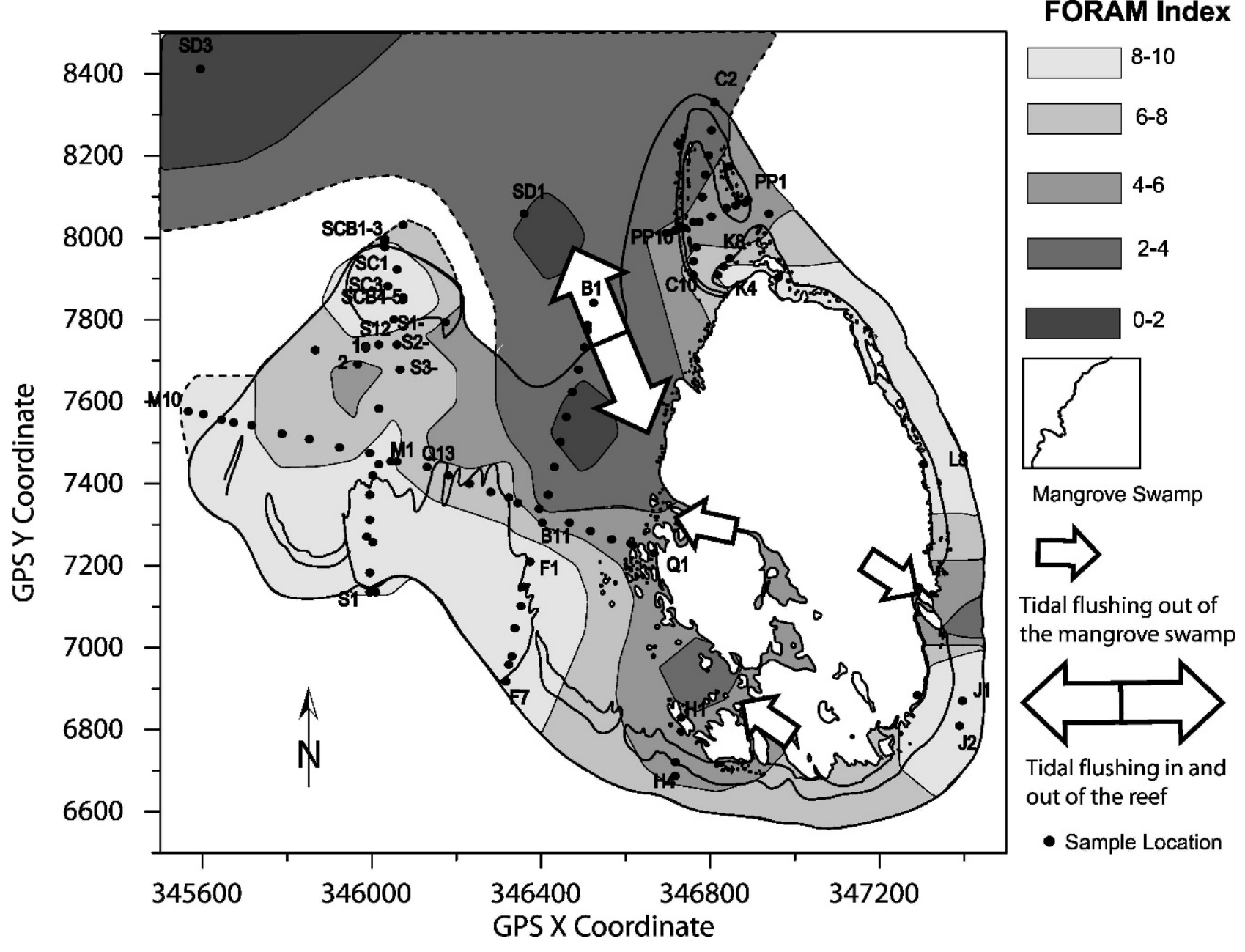

FIgURE 4. Contour map of FI values on Low Isles Reef. Also shown are sampling locations.

workers have attributed the changes to increased agricultural activity in nearby coastal catchments, and suggested that nutrient concentrations in some nearshore areas of the Great Barrier Reef have reached a critical level for the survival of corals in fringing reefs (Bell, 1991, 1992; Bell and Elmetri, 1995). Others, noting that the changes are restricted largely to the Anchorage, have suggested a more local source of nutrients, namely the Low Isles mangrove swamp (Frank and Jell, 2006). The swamp contributes to the reef flat leaf debris and bird guano, deposited by thousands of Torres Strait Pigeons that nest in the swamp between September and March. Areas proximal to the mangrove swamp are characterized by sea grass and macroalgal growth denser than more distal regions, suggesting relatively eutrophic conditions. Moreover, because the Anchorage serves as the main conduit through which water enters and exits the reef flat during the tidal cycle, it is likely that much of the suspended sediment and swamp debris end up in the Anchorage. Frank and Jell (2006) postulated that an increasing contribution of leaf litter and bird guano since 1928 as the swamp expanded could have increased the fertility of sediments in the Anchorage. Frequent resuspension of bottom sediment by waves, currents and boat activity provides a means of releasing stored nutrients to the water column and creating locally eutrophic conditions. Moreover, if regional nutrient pulses associated with agricultural runoff are impacting Low Isles Reef, the effects would be seen first in the backreef areas, such as the Anchorage, because they are also subjected to more local nutrient sources.

Lower FI values in reef flat areas surrounding the mangrove swamp and in the Anchorage are consistent with the assertion by Stephenson and others (1958) that the decline in scleractinian coral following the 1950 cyclone was due to competition by relatively fast-growing soft-bodied corals and macroalgae and may indicate that conditions in that area were marginal at the time of the cyclone. The spatial distribution of the lower FI values is consistent with the suggestion by Frank and Jell (2006) that water quality in the Anchorage may be declining as the contribution of organic detritus from the mangrove swamp increases. Assuming no other perturbations to drainage patterns on the reef, it seems doubtful that scleractinian corals will ever recolonize the Low Isles Reef Anchorage. 


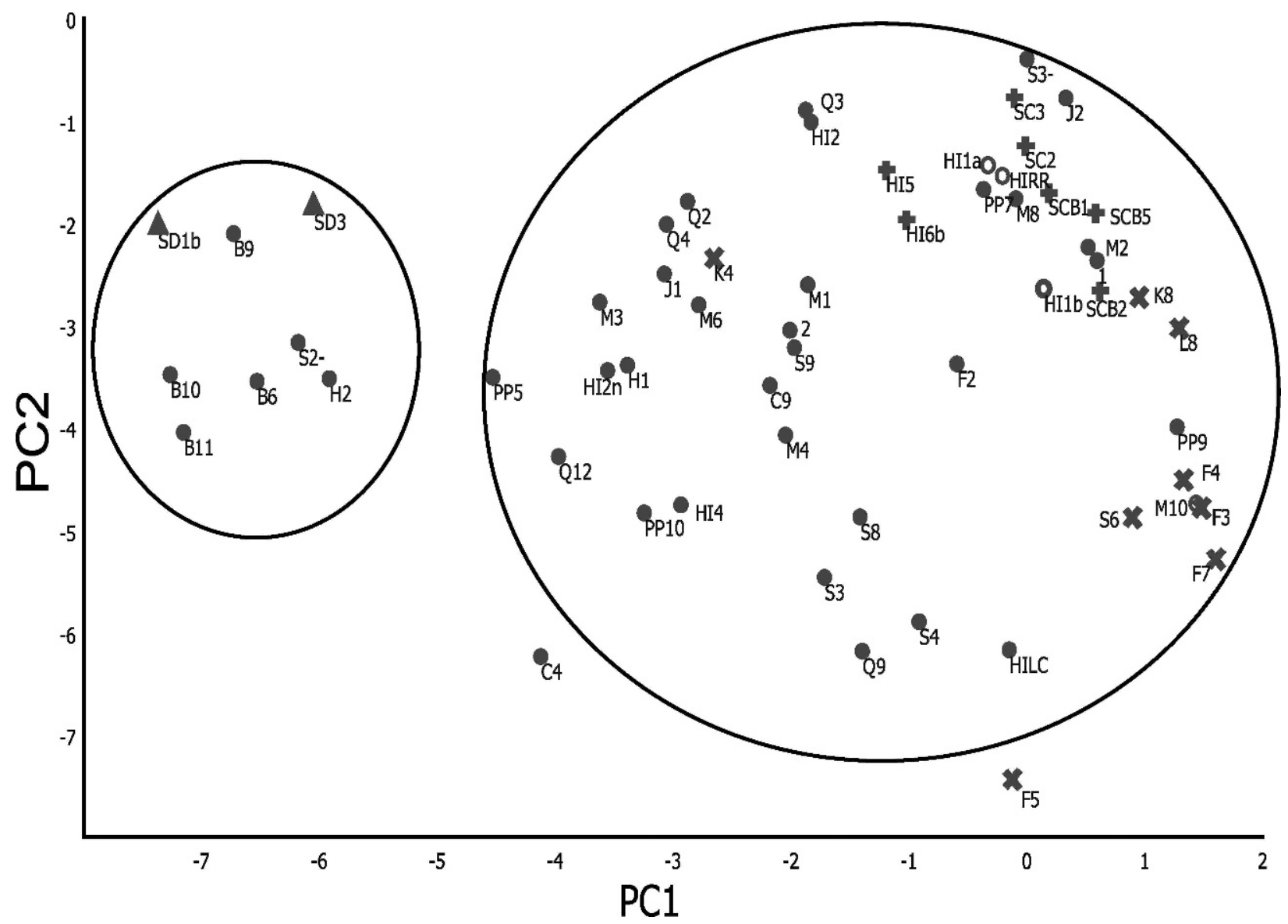

Figure 5. Results of the principal components analysis (scores). The samples are marked by five depositional environments: reef flat (black dots), sand cay $(+)$, shingle ramparts (x), anchorage (triangles) and reef rim (open circles). Two main groups are circled and appear to be constrained by FI values and not by any other factor. The scale is in units of each principal component.

\section{CONCLUSIONS}

The Foraminifera in Assessment and Monitoring (FORAM) Index of Hallock and others (2003) was applied to assess whether changes since 1928 in the coral population of Low Isles Reef, located in the wet tropics of the Great Barrier Reef Province, Australia, were related to land use activities that have increased the fluxes of sediment and nutrients to coastal areas (Bell 1991, 1992; Neil and Yu, 1996). To confirm in the Great Barrior Reef Province the reliability of the FORAM Index (FI), developed for use in the Caribbean, FI values were also determined for Heron Reef, which supports thriving colonies of scleractinian coral. The main conclusions are as follows.

1. Overall, FI values from Low Isles and Heron Reefs, respectively, are statistically indistinguishable and generally high $(\mathrm{FI}>4)$. These results suggest that conditions on both platforms are generally favorable for coral growth.

2. Lower FI values, which highlight areas that are marginal $(\mathrm{FI}=2$ to 4$)$ or unsuitable $(\mathrm{FI}<2)$ for coral growth, are concentrated in the Low Isles Anchorage and areas of the reef flat that lie directly west of the mangrove swamp that occupies the eastern half of the reef top. This distribution is consistent with observations by previous workers (Stephenson and others, 1958; Bell and Elmetri, 1995), that scleractinian corals in these areas were unable to recover from damage inflicted by a 1950 cyclone. We speculate that nutrification in these particular locations is related to the contribution of organic debris from the adjacent mangrove swamp, but cannot rule out a compounding effect from regional nutrient pulses.

3. The dominance of high FI values $(F I>4)$ suggests that activities on the mainland, which may have increased the fluxes of sediment and nutrients to coastal areas, have not significantly impacted water quality near Low Isles Reef. Results are consistent with previous studies that suggest that strong northwesterly currents along the shoreface inhibit transport of terrigenous sediment across the shelf (Orpin and others, 1999; Larcombe and Woolfe, 1999; Larcombe and Carter, 2004).

4. The distribution and magnitude of FI values on Low Isles and Heron Reefs are consistent with ground observations and conclusions drawn from previous studies. As such, results indicate that the FI provides a reliable proxy for water quality and coral reef health in the Great Barrier Reef Province and does not rely on depositional environment or water depth. 


\section{ACKNOWLEDGMENTS}

Funding was provided by an Undergraduate Creative and Research Experience (UCARE) grant to JS from the University of Nebraska-Lincoln (UNL). We thank D. Harwood for aiding with identification foraminifera, and for the use of the H. V. Andersen foraminifera collection in the Department of Geosciences at UNL. We are greatful to D. Watkins for insightful discussions. We thank P. HallockMuller and two anonymous reviewers for comments and suggestions that led to significant improvements in the manuscript.

\section{REFERENCES}

BELL, P. R. F., 1991, Status of eutrophication in the Great Barrier Reef lagoon: Marine Pollution Bulletin, v. 23, p. 89-93.

1992, Eutrophication and coral reefs-some examples in the Great Barrier Reef lagoon: Water Research, v. 26, p. 553-568.

, and Elmetri, I., 1995, Ecological indicators of large-scale eutrophication in the Great Barrier Reef Lagoon: Ambio, v. 24, p. $208-215$.

Bryant, D., Burke, L., McManus, J., and Spalding, M., 1998, Reefs at risk: A Map-based Indicator of Potential Threats to the World's Coral Reefs: World Resources Institute, Washington, D.C. (website: www.wri.org/indictrs/reefrisk.htm).

Cockey, E. M., Hallock, P., and Lidz, B. H., 1996, Decadal-scale changes in benthic foraminiferal assemblages off Key Largo, Florida: Coral Reefs, v. 15, p. 237-248.

Donnelly, K. B., 1993, Characterization of the foraminiferal assemblage off the southwest coast of Puerto Rico at La Parguera: Unpublished M. Sc. Thesis, University of South Florida, Tampa, Florida, $272 \mathrm{p}$.

Fairbridge, R. W., and Teichert, C., 1947, The rampart system at Low Isles 1928-1945: Reports of the Great Barrier Reef Committee, v. 6, p. 1-16.

, and -1948 , The Low Isles of the Great Barrier Reef; a new analysis: Geographical Journal, v. 11, p. 67-88.

Flood, P. G., Orme, G. R., and Scoffin, T. P., 1978, An analysis of the textural variability displayed by interreef sediments of the impure carbonate facies in the vicinity of the Howick Group: Philosophical Transactions of the Royal Society of London, ser. A, v. 291 , p. $73-83$.

Frank, T. D., and Jell, J. S., 2006, Recent developments on a nearshore, terrigenous-influenced reef: Low Isles Reef, Australia: Journal of Coastal Research, v. 22, no. 3, p. 474-486.

FolK, R. L., 1957, Petrology of Sedimentary Rocks: University of Texas-Austin, Austin, TX, $111 \mathrm{p}$.

Gandhi, S., Rajamanickam, G. V., and Nigam, R., 2002, Taxonomy and distribution of benthic foraminifera from the sediments of Palk Strait, Tamil Nadu, east coast of India: Journal of the Palaeontological Society of India, v. 47, p. 47-64.

Guimerans, P. V., and Currado, J. L. C., 1999, Distribution of Planorbulinacea (benthic foraminifera) assemblages in surface sediments on the northern margin of the Gulf of Cadiz: Spanish Institute of Oceanography Bulletin, v. 15, p. 181-190.

HAllock, P., 1999, Chapter 8. Symbiont-bearing Foraminifera, in Sen Gupta, B. (ed.), Modern Foraminifera: Kluwer Press, Amsterdam, p. $123-139$.

- 2000, Symbiont-bearing foraminifera: harbingers of global change?: Micropaleontology, v. 46, supplement no. 1, p. 95-104.

- Lidz, B. H., Cockey-Burkhard, E. M., and Donnelly, K. B., 2003, Foraminifera as bioindicators in coral reef assessment and monitoring: the FORAM Index: Environmental Monitoring and Assessment, v. 81, no. 1-3, p. 221-238.

Hopley, D., 1982, The Geomorphology of the Great Barrier Reef: Quaternary Development of Coral Reefs: John Wiley and Sons, Inc., New York, $453 \mathrm{p}$.

Jell, J. S., Maxwell, W. H. G., and McKellar, R. G., 1965, The significance of the larger foraminifera in the Heron Island Reef sediments: Journal of Paleontology, v. 39, no. 2, p. 273-279.
Larcombe, P., and CARTer, R. M., 2004, Cyclone pumping, sediment partitioning and the development of the Great Barrier Reef shelf system, a review: Quaternary Science Reviews, v. 23, no. 1-2, p. $107-135$.

, and Woolfe, K. J., 1999, Note: increased sediment supply to the Great Barrier Reef will not increase sediment accumulation at most coral reefs: Coral Reefs, v. 18, p. 163-169.

- Ridd, P. V., Wilson, B., and Prytz, A., 1995, Factors controlling suspended sediment on inner-shelf coral reefs, Townsville, Australia: Coral Reefs, v. 13, p. 163-171.

LOBEGEIER, M. K., 2002, Benthic foraminifera of the family Calcarinidae from Green Island Reef, Great Barrier Reef province: Journal of Foraminiferal Research, v. 32, no. 3, p. $201-216$.

Manton, S. M., and Stephenson, T. A., 1935, Ecological surveys of coral reefs: Scientific Reports of the Great Barrier Reef Expedition 1928-29, British Museum (Natural History), v. 3, p. 274-312.

Mather, P., and Bennet, I. (eds.), 1993, A Coral Reef Handbook: A Guide to the Geology, Flora, and Fauna of the Great Barrier Reef, 3rd edition: Surrey Beatty and Sons Pty Limited, Chipping Norton, Australia, $264 \mathrm{p}$.

Maxwell, W. G. H., 1968, Atlas of the Great Barrier Reef: Elsevier Publishing Company, New York, $258 \mathrm{p}$.

McLean, R. F., and StODDART, D. R., 1978, Reef island sediments of the northern Great Barrier Reef: Philosophical Transactions of the Royal Society of London, ser. A, v. 291, p. 101-117.

Moorhouse, F. W., 1936a, The recently formed natural breastwork on Low Isles: Reports of the Great Barrier Reef Committee, v. 4, p. 35-36.

- 1936b, The cyclone of 1934 and its effects on Low Isles, with special observations on Porites: Reports of the Great Barrier Reef Committee, v. 4, p. 37-44.

NeIL, D. T., and Yu, B., 1996, Fluviatile sediment yield to the Great Barrier Reef lagoon: spatial patterns and the effect of land use, in Hunter, H. J., Eyles, A. G., and Rayment, D. E. (eds.), Downstream Effects of Land Use: Department of Natural Resources and Mines, Queensland, Australia, Brisbane, Australia, p. 281-286.

Orme, G. R., Flood, P. G., and Sargent, C. E. G., 1978a, Sedimentation trends in the lee of outer (ribbon) reefs, Northern Region of the Great Barrier Reef Province: Philosophical Transactions of the Royal Society of London, ser. A, v. 291, p. 85-99.

- Webb, J. P., Kelland, N. C., and Sargent, G. E. G., 1978b, Aspects of the geological history and structure of the northern Great Barrier Reef: Philosophical Transactions of the Royal Society of London, ser. A, v. 291, p. 23-35.

Orpin, A. R., RidD, P. V., and Stewart, L. K., 1999, Assessment of the relative importance of major sediment-transport mechanisms in the central Great Barrier Reef lagoon: Australian Journal of Earth Sciences, v. 46, no. 6, p. 883-896.

Rayment, G. E., and Neil, D. T., 1996, Sources of material in river discharge, in Anonymous. (ed.), The Great Barrier Reef: Science, Use, and Management, Proceedings, v. 1, p. 42-58.

Searle, D. E., Harvey, N., and Hopley, D., 1980, Preliminary results of continuous seismic profiling on the Great Barrier Reef province between $16^{\circ} 10^{\prime} \mathrm{S}$ and $19^{\circ} 20^{\prime} \mathrm{S}$ : Geological Survey of Queensland Record, v. 23, p. 32.

Stephenson, T. A., EndeAn, R., and Bennett, I., 1958, An ecological survey of the marine fauna of Low Isles, Queensland: Australian Journal of Marine and Freshwater Research, v. 9, no. 2, p. 261-318.

- Stephenson, A., Tandy, G., and Spender, M. A., 1931, The structure and ecology of Low Isles and other reefs: Scientific Reports of the Great Barrier Reef Expedition 1928-29, British Museum (Natural History), v. 3, no. 2, p. 17-112.

Stoddart, D. R., Mclean, R. F., Scoffin, T. P., and Gibbs, P. E., 1978, Forty-five years of change on low wooded islands, Great Barrier Reef: Philosophical Transactions of the Royal Society of London, ser. B, v. 284, p. 63-80.

WILKINSON, C., 2000, Status of coral reefs of the world: 2000: Global Coral Reef Monitoring Network, Australian Institute of Marine Science, Townsville, http://www.aims.gov.au/pages/resarch/ coral-bleaching/scr2000/scr-00.html. 
Williams, D. M., 2001, Impacts of Terrestrial Run-off on the Great Barrier Reef World Heritage Area: CRC Reef Research Centre, Townsville, Australia, $52 \mathrm{p}$.

Woolfe, K. J., and LARCOMBe, P., 1998, Terrigenous sediment accumulation as a regional control on the distribution of reef carbonates, in Camoin, G. F., and Davies, P. J. (eds.), Reefs and Carbonate Platforms in the Pacific and Indian Oceans (Special Publication of the International Associa- tion of Sedimentologists, No. 25, Aix-en-Provence, France): Blackwell Publishing, Malden, Massachusetts, p. 295-310.

Yonge, C. M., 1930, A Year on the Great Barrier Reef: The Story of Corals and of the Greatest of Their Creations: Putnam, London, UK, $246 \mathrm{p}$.

Received 30 July 2007 Accepted 24 September 2007 